\title{
Analysis of Leadership Effect and Public Service Motivation on Work Satisfaction (ASN) In The District Bantaeng
}

\author{
Jumiaty Nurung*, Rakhmat**, Sulaeman Asang**, Hamsinah ** \\ *Graduate Student PhD, Study Program : Science Of Public Administration. Hasanuddin University, Makassar, Indonesia \\ ** Faculty of Social and Political Sciences, Hasanuddin University, Makassar, Indonesia \\ Email : jum.unhas@yahoo.com
}

\begin{abstract}
This research was conducted to determine the effect of leadership and motivation of public service for job satisfaction ASN Bantaeng district. Basically, job satisfaction is an individual thing and depends on one's perception of what he feels about work. Further explained that the job satisfaction theory tries to reveal what makes some people more satisfied with their work than some others. If employees have high job satisfaction, employees will try to show the best service quality. Job satisfaction in this study as a central point that can not only affect the quality of public services directly, but can be a factor that mediates indirect effects of several factors that affect the quality of public services, including leadership factors and motivation for public services. Leadership has a positive direct effect, although not significantly on ASN job satisfaction, while the activation of public services has a significant positive direct effect on ASN job satisfaction in Bantaeng District .
\end{abstract}

Keywords : leadership, work motivation, public service,

\section{INTRODUCTION}

One of the aspects that affect the quality of public services provided is job satisfaction, that is to say with a high level of employment kepusan usually employees will provide good service and vice versa, when the employee is not satisfied with the job the services provided will not be satisfactory. Thus, job satisfaction is a driving factor in increasing the quality of public services that contribute both directly and to the factors that mediate other external factors. This is in line with what was stated by Trivellas, Jacques, and Dargenidou (2009) who in his research findings argue that "employees not only provide and create services, but are actually part of service", thus, their satisfaction drives service quality. Furthermore, the results of the study of Sunaryo and Suyono (2013) indicate that motivation for public services has a significant and positive effect on job satisfaction. The significant impact of public service motivation on job satisfaction as found in this study shows that high public service motivation will result in high job satisfaction. These results are in line with Liu, Tang, and Zhu (2008) who have shown that motivation for community service has a strong impact on job satisfaction of public sector employees in China. Then the results of Taylor (2007) research, which found that there was a significant relationship between motivation for public services and individual performance, where job satisfaction is the main attitude of employees in the public sector.

In general, job satisfaction reflects the feelings of workers on their jobs. According to (Robbins, 2007) that job satisfaction is a general attitude of an individual to work where someone with a high level of job satisfaction shows a positive attitude towards work. (Hartatik, 2014) further explains that the job satisfaction theory tries to express what makes some people more satisfied with their work than some others. Basically, job satisfaction is an individual thing and depends on one's perception of what he feels about work. Further explained that the job satisfaction theory tries to reveal what makes some people more satisfied with their work than some others. If employees have high job satisfaction, employees will try to show the best service quality. This is in line with (Panggabean \& Mutiara, 2004), which states that basically job satisfaction depends on what someone wants from his job and what he gets. Several factors can increase employee job satisfaction as stated (As'ad, 2003) that are opportunities for advancement, namely: job security, salary, corporate environment and management, intrinsic factors and work, working conditions, social aspects of work, communication, and amenities. In line with these opinions, job satisfaction as a mediating variable in improving service quality in this study is directly influenced by transformational leadership, work discipline, work environment and appreciation.

Leadership is one of the important elements in increasing job satisfaction and quality of public services. Piccolo and Colquitt (2006) argued that transformational leadership has been two decades emerged as one approach to understanding keefekti fit asan lead. It is this transformational leadership that truly means true leadership because this leadership really works towards the goal that directs the organization to a goal that was never achieved before (Locke, 1997). Furthermore, transfomational leadership is characterized by the behavior of leaders to raise subordinates to a higher level, (Bass, 1985 ; Burns, 1978).

A leader is said to be transformational in style if it can change the situation, change what is usually done, talk about a noble goal, have a reference to the values of freedom, justice and equality. Transformational leaders will make subordinates see that the goals to be achieved are more than just their personal interests. Transformational leadership has been the main research theme for the past two decades. Empirical findings from previous studies reported that transformational leadership improves employee attitudes and performance (Bass, 1997 ; Lowe, Kroeck, \& Sivasubramaniam,1996). In addition, some previous research 
findings also show that leadership has a significant effect on job satisfaction (Plangiten, 2013 ; Widodo, 2014) and also has an impact on improving service quality (Hariri, 2011 ; Hati, 2013 ; Munwar Hussain Pahi \& Kamal Ab Hamid, 2015). Furthermore, leader behavior is significantly related to the behavior and responses of followers, such as employee satisfaction, efforts to selfreport, task performance, and role clarity (Podsakoff, Ahearne, \& MacKenzie,1997) . Furthermore, research (Judge \& Bono, 2000) found that transformational leader behaviors influence job satisfaction and subordinate satisfaction with their leaders. Thus, if the leadership is more charismatic and understands subordinates it will be able to create employee job satisfaction so that it has an impact on the quality of public services.

Various studies in America and Europe found that public service motivation (Public Service Motivation) has a significant effect on service quality and job satisfaction as done by ( HG Rainey \& Steinbauer, 1999 ), who conducted a study by improving findings (Brewer \& Selden, 1998) . Based on the results of the study (Clerkin \& Coggburn, 2012) found that the increasing motivation of public services will cause an increase in job satisfaction which in turn improves the quality of service for employees in the public sector. The results of the study (Wright \& Grant, 2010) found that people who have motivated public service tend to work in the public sector compared to the pro fit sector .

Research conducted by (Pandey, Wright, \& Moynihan, 2008 ; Wright, Moynihan, \& Pandey, 2012) strengthens research on people's interest in motivating public services to work in the public service sector but has not been able to answer why it is different. Finally, the results of the study (Syamsir, 2016) on all local government employees of West Sumatra Regency found things that were different from findings in America and Europe in general. His findings indicate there is influence but the effect is very small, which is only $2.6 \%$. At this point this study will prove how the relationship between the motivation of public services and job satisfaction and the quality of public services in the Bantaeng District Government departs from the differences in the results of this study.

The description that has been stated previously has shown that the quality of public services can be improved through increasing employee job satisfaction. Job satisfaction in this study as a central point that can not only affect the quality of public services directly, but can be a factor that mediates indirect effects of several factors that affect the quality of public services, including leadership factors and motivation for public services. Based on the meta-analysis which included 6,746 people consisting of 28 separate studies revealed a positive and significant relationship between good organizational member behavior and satisfaction (Organ, 1995). Furthermore (Robbins, 2007) explains that it is logical to consider satisfaction as the main predictor of someone's extra role behavior, because satisfied employees tend to talk positively about the organization, help other individuals, and pass normal expectations in their work. In addition, satisfied employees may give more roles because they respond to their positive experiences so that they will improve the quality of their services.

\section{RESEARCH METHODS}

The method used in this study is inferential quantitative method (statistics with Structural Equation Modeling -SEM) which can analyze the relationship between variables to the indicators of each variable. This research was conducted in Bantaeng Regency where the object of research was all local government organizations (OPD) in Bantaeng District Government. Data collection methods used in this study consist of two, namely:

1. Observation, namely data collection carried out directly to the place of research through observation of the object under study or things that are needed specifically related to the variable under study .

2. Questionnaire, which is collecting data by distributing questionnaires (questionnaires) to respondents (research samples) to answer the problem in this study.

3. In-depth interviews (in-depth interviews) if required, the process of obtaining information for research purposes by way of question and answer face to face between the interviewer and respondent or person diwawncarai, with or without the use of a guide (guide) interview in which the interviewer and the informant involved in relatively long social life (Sutopo, 2006) .

\section{RESULTS AND DISCUSSION}

The quality of public services in public organizations is in the spotlight and that is where the hope of society depends. With the quality of good public service, people will be calm because they believe that each of their affairs will be served with the maximum. The government is required to find solutions to every problem faced by the community with innovation and renewal of government management (Rachmat, 2018) where in it must think of ASN as the main element in service. The research provides an overview of the relationship between leadership and public service motivation, job satisfaction in ASN in Bantaeng District.

\section{a. Direct influence of leadership on job satisfaction}

Leadership is believed to have an influence on ASN job satisfaction as it has become the belief of experts with various research results in the private sector. Some of the results of research in the private sector show that leadership, both transformational leadership and transactional leadership have contributed to increasing ASN job satisfaction. The results showed that the leadership influence coefficient (KPM) on job satisfaction (KPK) was 0.006 with a t-count value of 0.028 at a significance level of 0.978 . The coefficient shows that leadership (KPM) has a positive effect on job satisfaction (KPK) of 0.006 . While t-count (CR) is only equal to 0.028 smaller than 2.0 as the cut of point (Ferdinand, 2014 ; Joseph F. Hair Jr et al., 2014 ) which means that the effect of leadership is not significant on job satisfaction. This means that increasing leadership (KPM), will 
be followed by an increase in job satisfaction (KPK); on the contrary, a decrease in leadership (KPM), will be followed by a decrease in job satisfaction (KPK), assuming other factors that affect the size of job satisfaction (KPK) are considered constant even though this is not significant.

The results of the study also showed contributions from leadership-forming indicators consisting of transformational leadership and transactional leadership. The biggest contribution to leadership is transactional leadership, this can be seen from the estimated value ( loading factor on standardized regression weights ) as much as 0.769 is greater than transformational leadership that is equal to 0.751 . The interesting thing is that if we look at the forming items of the two indicators, it will be seen that the biggest contribution is derived from transformational leadership, namely 1) encouraging employees to appear /advance (0.775), 2) increase employee motivation (0.765), and 3) encourage employees to think more creatively (0.686). While items forming transactional leadership are in the order of 4) making standards for doing work (0.683), 5) taking action before chronic problems (0.601), and 6) making clear expectations (0.557), and the most recent are items in Transformational leadership is listening to employee concerns (0.554). These results indicate that a transformational leader is expected to be a motivator and guide ASN to be creative in work, while transactional leaders are expected to be able to make clear standards, ability to make decisions, and as good listeners.

The results showed that ASN job satisfaction can be improved with good leadership even though this is not significant. This is because basically ASN job satisfaction is formed from the largest contribution forming indicators of ASN job satisfaction respectively 1 ) jobs in general $(0.747), 2$ ) coworkers (0.709), 3) supervision (0.694), and 4) salary currently (0.561). The entire indicator is a factor that comes from the environment in which the ASN is located and the direct contribution of the leader is minimal. Basically ASN in Bantaeng Regency is in the field where they already feel that they are compatible with the ASN which is supported by good relations between the ASN itself which contributes to their satisfaction with their work. Current supervision and salary is one of the direct contributions of the leader but salaries for ASN adjust to their rank and class so that even this cannot make satisfaction for ASN due to good leadership. While supervision is formed by 3 (three) items, namely the leader gives flexibility to ASN but assesses the work objectively, always around if needed, and knows the job well, also not maximally contributing to ASN job satisfaction. Based on the results of interviews with several informants, especially ASN who held positions (echelon 2-4) said that the current leadership they had very strict supervision in which each leader in each unit must stand by 24 hours, and anyone contacted by the highest leadership in the district Bantaeng and does not respond to 2 or 3 times the call must be prepared to be transferred. Even though they were satisfied with their work but they felt that there was a strong pressure from the leadership so the researchers considered that this was one of the factors that made leadership not significant to ASN job satisfaction in Bantaeng District.

The results of this study contradict the findings which state that good leadership significantly increases ASN job satisfaction and vice versa, as the results of research (Paripurna, 2013) show that leadership variables have a partially significant effect on employee job satisfaction. The leadership variable becomes the most dominant variable that influences employee job satisfaction because based on analysis calculations the standardized beta coefficients have the greatest value. Furthermore, research shows that transformational leadership has a greater contribution compared to transsexional leadership on job satisfaction (Ahmad, Adi, Noor, Rahman, \& Yushuang, 2013) in line with that ( Aloysius, 2017 ; Seung-Ho, Meier, \& Ladenburg, 2008 ).

Other studies that see direct influence of leadership on job satisfaction include, (Voon, Lo, Ngui, \& Ayob, 2011 ; Wan Omar \& Hussin, 2013 ; Yunus \& Bachri, 2013) with a significant positive influence, furthermore the research conducted by (Long et al., 2014a) showed that only one of the four characteristics of transformational leadership was found to have a significant relationship with job satisfaction. Characteristics of individual considerations found most contribute to job satisfaction. Research (Judge \& Bono, 2000) me nemukan that transformational leaders' behaviors influence job satisfaction and subordinate satisfaction with their leaders. While research is in line with the findings in this study, where there is a positive but not significant relationship (Budiyanto \& Oetomo, 2011) the research was conducted in Magetan Indonesia . Furthermore, the more extreme is the finding that leadership has a negative and significant effect on employee job satisfaction, meaning that the results of executing managerial activities of leadership do not necessarily have an always positive or good impact for the organization, because the higher the leadership managerial activities are carried out. will have an impact on decreasing company performance from time to time. The implementation of more leadership activities in the direction of pressing employees can cause an employee to achieve satisfaction in work, but not necessarily able to bring a positive influence in the formation of subordinate personality to sincerely work towards achieving organizational goals (Brahmasari \& Suprayetno, 2008) .

The style of a leader in managing an organization is said to have a large role in employee performance and transformational leadership is considered as one of the most effective styles applied in a work environment that is believed to have an impact on employee job satisfaction (Belias \& Koustelios, 2014). Other research on a bank shows that transformational leadership has no significant effect on job satisfaction even though in general influential leadership then communication and interaction can be emphasized as the main pillar of a leader (Cetin, Karabay, \& Efe, 2012).

Leadership in this study is defined as the ability possessed by a leader in influencing his subordinates based on transformational and transactional styles through intelligence, maturity, social relations and self-motivation in order to achieve organizational goals. This variable is measured by indicators based on (Bass, 1997 ; Yuki,2010) , namely transformational leadership, and transactional leadership. To be able to display charming leadership in Bantaeng District government organizations, the leadership dimension must be designed so that it can create a positive positive response to employees.

The initial idea of transformational leadership theory was developed by (Burns, 1978 ; G. Yuki, 1994) based on descriptive research on political leaders. Conceptually Burns introduces two types of leadership, namely transactional leadership and transformational leadership, where the two types of leadership are different but positively related rather than conflicting styles. (Bass, 1985) views transactional leadership and transformational leadership as different processes, and he recognizes that the same leader can use both types of leadership at different times and situations. This opinion is supported by (Waldman et al., 1987 
) who argues that, although the concept is different, transactional leadership and transformational leadership can be adopted at a certain level by a manager, and that the most effective leaders are transactional and transformational leaders. If leadership is effective in showing leadership, the impact is on satisfaction of employees.

Leadership characterized by transformational and transactional dimensions has a positive but not significant effect on ASN job satisfaction, this is because the main driving factors for ASN job satisfaction are good relationships with colleagues, work in general, and the salary they receive. Thus the factors that come from their leaders are only salaries, but salaries for ASN have been stipulated in accordance with the applicable rules based on rank and class of the ASN. Furthermore, ASN in Bantaeng Regency does not receive additional income as received by ASN elsewhere.

The results of this study also prove that theoretical studies and empirical studies that state and prove the existence of a positive although not significant causality relationship (the effect is very small) between leadership and job satisfaction and the quality of public services. The implication of this finding is that leadership is not a major driver of increasing ASN job satisfaction. By that, it should pay attention to leadership, especially 4 (four) transformational leadership drivers and 3 (three) transactional leadership drivers as explained before, although this does not have a significant effect.

\section{c. Direct influence of public service motivation on job satisfaction}

The study of the motivation of public services in Europe and America is very large, but similar studies in ASEAN are still very rare, especially in Indonesia. From various research results, it shows that there is a positive relationship between motivation of public services and job satisfaction and quality of public services, both in Europe and America and in Indonesia. One of the studies in Indonesia is carried out in West Sumatra with very little results, which is only $2.6 \%$ different from the results found in Europe and Amerika.

Public service motivation activation (PSM) on job satisfaction (KPK) is 0.683 with at value of 3.855 greater than 2.0 as a cut of point (Ferdinand, 2014 ; Joseph F. Hair Jr et al., 2014) at a significance level of 0,000. The coefficient shows that the public service motivation variable (PSM) has a positive effect on job satisfaction (KPK). This means that increasing public service motivation (PSM), will be followed by increased job satisfaction (KPK); on the contrary, a decrease in public service motivation (PSM), will be followed by a decrease in job satisfaction (KPK), assuming other factors that affect the size of job satisfaction (KPK) are considered constant.

The confirmatory test results also provide an interpretation that of the four indicators used to measure public service motivation, respondents respond to compassion, commitment to the public interest (commitment to the public interest ) as the dominant indicator is considered by employees, this is evidenced by an estimated value of 0.959 and 0.814 which is greater than other indicators. So that as far as possible the Bantaeng District government pays more attention to aspects of compassion and commitment to the public interest (commitment to the public interest ).

The results found in the study were that public service motivation driven by feelings of compassion, commitment to the public interest, and interest in policy making could increase ASN job satisfaction (Liu et al., 2008) . Furthermore, it is rather different from the results of research that see the relationship between motivation in general and job satisfaction (Ferawaty \& Tamsah, 2016 ; Lambrou, Kontodimopoulos, \& Niakas, 2010), although the effect is the same, which is positive and significant.

To maintain employee job satisfaction, it is necessary to have good public service motivation. Motivation of public services in this study are government employees who have the desire to serve the public or a public employee will be involved in behavior that is consistent with community-oriented motives and altruistic attitudes (selflessness). This variable is measured by indicators based on (Perry,1996) and developed (Coursey \& Pandey, 2007 ; Coursey et al., 2008) as follows: interest in public policy making (attraction to public policy making), a commitment to the public interest (commitmen to the public interest), mercy (compassion), and self-sacrifice (self-sacrifice).

The concept of motivation of public servants (Vandenabeele 2007) has been developed as a counterbalance to the motivation of self-interest (self interst) found in the theory of rational pilhan. Whereas according to (Willem et al., 2010) the concept of motivation for public services was introduced to show motivation based on values and attitudes beyond self-interest or organizational interests.

The motivation of ASN in the perspective of the PSM theory is formed by intrinsic and extrinsic reward factors . Intrinsic reward is the satisfaction of an ASN because it has done a work that means for example, feelings of satisfaction, pride and pride. While extrinsic rewards are rewards received by ASN from the government, such as salary increases, promotions, job security, status and pestise. PSM is not only driven by the compensation factor alone, but also factors of satisfaction (satisfaction).

PSM does not view reward factors as important instruments in increasing ASN motivation because motivation is formed by intrinsic and extrinsic factors. So far, the government has tended to only emphasize extrinsic factors, namely by increasing salaries, benefits, promotions without regard to ASN satisfaction factors towards their work. It is predictable that the results will not be effective because ASN is positioned as a human economy that only emphasizes material aspects. In fact, ASN also wants to be respected for its existence, wants to do something that is in accordance with its abilities and expertise, so that they are satisfied to serve the nation and the State. That is, ASN has altruism values, namely values do something for the benefit of many people.

Evidence from the results of previous studies confirms that job satisfaction is influenced by public service motivation, (Rainey \& Steinbauer, 1999), who conducts studies by improving findings (Brewer \& Selden, 1998) . Furthermore, the results of the study (Clerkin \& Coggburn, 2012) found that the increasing motivation of public services will lead to an increase in job satisfaction which further increases the quality of service for employees in the public sector. Furthermore, research on people's interests has a motivation for public service to work in the public service sector but has not been able to answer why it is different (Moynihan \& Pandey, 2007 ; Pandey et al., 2008). 
The results of this study also prove that theoretical studies and empirical studies state and prove the existence of a positive and significant causality relationship between motivation for public services and employee job satisfaction. The implication of this finding is that increasing public service motivation, which consists of feelings of compassion, commitment to the public interest, and interest in policy making are the main drivers of increasing ASN job satisfaction in Bantaeng District. Therefore, the motivation of public service which consists of the spirit of self-sacrifice, commitment to the public interest, the spirit of compassion, and interest in making policy on the ASN are of concern.

\section{CONCLUSION}

1. Leadership has a positive direct effect even though it is not significant for ASN job satisfaction in Bantaeng District. These results indicate that enhanced leadership is characterized by encouraging employees to perform/advance, increase employee motivation, encourage employees to think more creatively, and listen to employee concerns (transformational leaders) and better standards for doing work, taking action before chronic problems, and making clear expectations (transactional leadership) will increase the ASN job satisfaction in Bantaeng Regency.

2. Motivation of public services has a significant positive direct effect on ASN job satisfaction in Bantaeng District. These results indicate that the better the ASN public service motivation which is marked by improvement in compassion, commitment to the public interest, interest in policy making has implications for increasing ASN job satisfaction in Bantaeng District.

\section{REFERENCES}

1. Ahmad, A. R., Adi, MNM, Noor, HM, Rahman, AGA, \& Yushuang, T. 2013. The Influence of Leadership Style on Job Satisfaction among Nurses. Asian Social Science, 9 (9). doi: 10.5539 / ass.v9n9p172

2. Aloysius, SMCM 2017. Transformational - Transaction Leadership and Employees' Job. Asia Pacific Journal of Research; ISSN (Print): 2320-5504; ISSN (Online): 2347-4793 .

3. As'ad , M. 2003. Industrial Psychology: Human Resource Series : Yogyakarta: Liberty.

4. $\quad$ Bass, BM 1985. Leadership and performance beyond expectations : New York: Free Press.

5. Bass, B. M. 1997. Does the Transactional-Transformational Leadership Paradigm Transcend Organizational and National Boundaries.

6. Belias, D. , \& Koustelios, A. 2014. Transformational Leadership and Job Satisfaction in the Banking Sector. International Review of Management and Marketing; Vol. 4, No. 3, 2014, pp. 187-200; ISSN: 2146-4405; www.econjournals.com .

7. Brahmasari, IA, \& Suprayetno, A. 2008. The Influence of Work Motivation, Leadership and Organizational Culture on Employee Job Satisfaction and Its Impact on Company Performance (Case study at PT. Pei Hai International Wiratama Indonesia). Journal of Management and Entrepreneurship, Vol. 10, No. 2, September 2008: 124-135 .

8. Brewer, GA, \& Seld en, SC 1998. Whistle Blowers in the Federal Civil Service: New Evidence of the Public Service Ethic. Journal of Public Administration Research and Theory, 8 (3), 413-440. doi: 10.1093 / oxfordjournals.jpart.a024390 .

9. Budiyanto, \& O etomo, HW 2011. The Effect of Job Motivation, Work Environment and Leadership on Organizational Citizenship Behavior, Job Satisfaction and Public Service Quality in Magetan, East Java, Indonesia. World Academy of Science, Engineering and Technology, International Journal of Social, Behavioral, Educational, Economic, Business and Industrial Engineering Vol: 5, No: 3, 2011.

10. Burns, JM 1978. Leadership : New York: Harper \& Row.

11. Cetin, M. , Karabay, ME, \& Efe, MN 2012. The Effects of Leadership Styles and the Communication Competency of Bank Employees' Job Job Satisfaction: The Case of Turkish Banks. Procedia - Social and Behavioral Sciences, 58 , 227-235. doi: 10.1016 / j.sbspro.2012.09.996

12. Clerkin, R. M., \& Coggburn, JD 2012. The Dimensions of Public Service Motivation and Sector Work Preferences. Review of Public Personnel Administration, 32 (3), 209-235. doi: 10.1177 / 0734371x11433880 . doi: 10.1177 / $0734371 X 11433880$ 
13. Coursey, DH, \& Pandey, SK 2007. Public Service Motivation Measurement: Testing an Abridged Version of Perry's Proposed Scale. Administration \& Society, 39 (5), 547-568. doi: 10.1177 / 0095399707303634

14. Coursey, D. H., Perry, JL, Brudney, JL, \& Littlepage, L. 2008. Psychometric Verification of Perry's Public Service Motivation Instrument. Review of Public Personnel Administration, 28 (1), 79-90. doi: 10.1177 / $0734371 x 07309523$.

15. Davido w, WH, \& Uttal, B. 1990. Total Customer Service: The Ultimate Weapon: The Six Point Plan for Giving Your Company New York: Harper \& Row Publisher.

16. Ferawaty , R., \& Tamsah, H. 2016. The Influence of Rewards and Motivation on the Job Satisfaction of Nurses of the Public Service Agency (BLU) at Makassar Bhayangkara Hospital. Mirai Management Journal, 2 (1), 14-23.

17. Ferdinan d, A. 2014. Structural Equation Modeling in Management Research, Application of Complex Models in Research for Thesis, Thesis, and Doctoral Dissertation : BP Undip-Undip Press. ISBN: 979-9156-75-0.

18. Hariri, R . E. 2011. Effect of Leadership Behavior on Academic Service Performance of Employees at the Indonesian Education University. Managerial Vol. 10, No. 19, July 2011: 32 - 41.

19. Hartati K, IP 2014. Practical Book Developing Yokyakarta HR : Laksana.

20. Hati, S. W. 2013. Effect of Leadership and Lecturer Performance on Service Quality at Batam State Polytechnic. Journal of Islamic Economics and Business Volume 9 Number 2 of 2013, ISSN: 1829-524X Department of Management, Faculty of Economics, UIN, Maulana Malik Ibrahim Malang .

21. Judge, TA, \& Bon o, JE 2000. The five-factor model of personality and transformational leadership. J Appl Psychol, 85 (5), 751-765.

22. Lambrou, P., Kontodimopoulos, N., \& Niakas, D. 2010. Motivation and job training among medical and nursing staff in a Cyprus public general hospital. Human Resources for Health, 8 (1), 26. doi: 10.1186 / 1478-4491-8-26

23. Liu, B., Tang , N., \& Zhu, X. 2008. Public service motivation and job satisfaction in China. International Journal of Manpower, 29 (8), 684-699. doi: 10.1108 / 01437720810919297

24. Locke, EA 1997. Essence of Leadership. Transfer language: Harsiwi Agung : Jakarta: Main Partner.

25. Long, CS, Yusof, WMM, Kowang, TO, \& Heng, LH 2014a. The Impact of Transformational Leadership Style on Job Satisfaction. World Applied Sciences Journal 29 (1): 117-124, 2014, ISSN 1818-4952, IDOSI Publications, 2014, DOI: 10.5829 / idosi.wasj.2014.29.01.1521.

26. Lowe, KB, Kroeck, KG, \& Sivasubramaniam, N. 1996. Effectiveness correlates of transformational and transactional leadership: A meta-analytic review of the MLQ literature. The Leadership Quarterly, 7 (3), 385-425. doi: https://doi.org/10.1016/S1048-9843(96)90027-2

27. Moynihan, DP, \& Pandey, SK 2007. The Role of Organizations in Fostering Public Service Motivation. Public Administration Review, 67 (1), 40-53. doi: 10.1111 / j.1540-6210.2006.00695.x .

28. Organ, DW, \& Ryan, K.. 1995. A Meta-Analytic Review of Attitudinal and Dispositional Predictors of Organizational Citizenship Behavior Personnel Psychology, 48 (4), 775-802. doi: http://dx.doi.org/10.1111/j.1744-6570.1995.tb01781.x

29. Pandey, SK, Wright, BE, \& Moynihan, DP 2008. Public Service Motivation and Interpersonal Citizenship Behavior in Public Organizations: Testing a Preliminary Model. International Public Management Journal, 11 (1), 89-108. doi: 10.1080 / 10967490801887947

30. Panggabean, S., \& Mutiara. 2004. Human Resource Management : Bogor: Ghalia Indonesia.

31. Paripurna, IGD 2013. Effect of Leadership, Work Environment and Communication on Employee Job Satisfaction Journal of the Faculty of Economics, Udayana University, Bali, 2013 - media.neliti.com .

32. Perry, JL 1996. Measuring Public Service Motivation: An Assessment of Construct Reliability and Validity. Journal of Public Administration Research and Theory: J-PART, Vol. 6, No. 1. (Jan., 1996), pp. 5-22.

33. Piccolo, RF, \& Colquitt, JA 2006. Transformational Leadership and Job Behaviors, The Mediating Role of Core Job Characteristics. The Academy of Management Journal, 2006, Vol. 49, No. 2, 327-340.

34. Plangiten, P. 2013. Leadership Style and Work Environment Its Impact on Employee Satisfaction at PT. Pos Indonesia (Persero) Manado. EMBA Journal; Vol.1 No.4 December 2013, pg. 2155-2166 . 
35. Podsakof, PM, Ahearne, M., \& MacKenzie, SB 1997. Organizational Citizenship Behavior and The Quantity and Quality of Work Group Performance. J Appl Psychol, 82 (2), 262-270.

36. Rainey, HG, \& Steinbauer, P.1999. Galloping Elephants: Developing Elements of the Theo ry of Effective Government Organizations. Journal of Public Administration Research and Theory, 9 (1), 1-32. doi: 10.1093 / oxfordjournals.jpart.a024401 .

37. Rakhmat. 2018. Administration and Public Accountability : Issue I, Yogyakarta: Andi, ISBN: 978-979-29-6196-6.

38. Robbins, SP 2007. Organizational Behavior, Issue 8 : Prentice Hall, Jakarta.

39. Seung-Ho, A. , Meier, KJ, \& Ladenburg, J. (2008). Leadership style and employee's job satisfaction in international tourist hotels, in Arch G. Woodside (ed.). Advances in Culture, Tourism and Hospitality Research (Advances in Culture, Tourism and Hospitality Research, Volume 2) Emerald Publishing Group Limited, pp.293 - 332.

40. Sunaryo, S., \& Suyono, J. 2013. A Test of the Relationship between Public Serv ice model . Rev. Integrity. The bus. Econ. Res. Vol 2 (1).

41. Syamsir. 2016. The Influence of Public Service Motivation on Service Quality of Civil Servants. European Journal of Economics and Business Studies, May-Aug 2016 ;, Vol. 5 Nr. 1 .

42. Taylor, J. 2007. The Impact of Public Service Motives on Work Outcomes in Australia: A Comparative Multi-Dimensional Analysis. Public Administration, Vol. 85 No. 4, pp., 931-959.2007.

43. Trivellas, P., Jacq ues, M., \& Dargenidou, D. 2009. Organizational culture, job satisfaction and higher education service quality. The TQM Journal, 21 (4), 382-399. doi: 10.1108 / 17542730910965083

44. Vandenabeele, W. 2007. Toward a public administration theory of public service . Public Management Review, 9 (4), 545556. doi: 10.1080 / 14719030701726697

45. Voon, M. L., Lo, MC, Ngui, KS, \& Ayob, NB 2011. Job satisfaction in public sector organizations in Malaysia. International Journal of Business, Management and Social Sciences, Vol. 2, No. 1, 2011, pp. 24-32 .

46. Waldman , DA, Bass, BM, \& Einstein, WO 1987. Leadership and Outcomes of Performance Appraisal Processes. Journal of Occupational Psychology, 60 (3), 177-186. http://dx.doi.org/10.1111/j.2044-8325.1987.tb00251.x .

47. Wan Oma r, WA, \& Hussin, F. 2013. Transformational Leadership Style and Job Satisfaction Relationship: A Study of Structural Equation Modeling (SEM). https: / www.researchgate.net/publication/259453673_Transformational_Leadership_Style_and_Job_Satisfaction_Relationship_A_ Study_of_Structural_Equation_Modeling_SEM.

48. Widodo, DS 2014. Influence of Leadership and Work Environment to Job Satisfaction and Impact to Employee Performance (Study on Industrial Manufacture in West Java). Journal of Economics and Sustainable Development. Vol.5, No.26, 2014.

49. Willem, A. , De Vos, A., \& Buelens, M. 2010. Comparing Private and Public Sector Employees' Psychological Contracts. Public Management Review, 12 (2), 275-302. doi: 10.1080 / 14719031003620323

50. Wright, BE, \& Grant, AM 2010. Unanswered Questions about Public Service Motivation: Designing Research to Address Key Issues of Emergence and Effects. Public Administration Review, October 2010.

51. Wright, BE, Moynihan, DP, \& Pandey, SK 2012. Pulling the Levers Transformational Leadership, Public Service Motivation, and Mission Valence. Public Administration Review, Vol. 72, Iss. 2, pp. 206-215. (C) 2011 by The American Society for Public Administration. DOI: 10.111 / j.1540-6210.2011.02496 .x.

52. Wright, B. E. , \& Pandey, SK 2008. Public Service Motivation and the Assumption of Person-Organization Fit: Testing the Mediating Effect of Value Congruence. Administration \& Society, 40 (5), 502-521. doi: 10.1177 / 0095399708320187

53. Yuki , G. 1994. Leadership in Organizations. 3rd Edition : Prentice Hall. Upper Saddle River.

54. Yunus, A. , \& Bachri, AA 2013. Effect of Work Discipline, Motivation, Leadership on Employee Job Satisfaction Study at PT. Bumi Barito Utama Banjarmasin Branch. Journal of Management Insights, Vol. 1, Number 2, June 2013. 
First Author - Jumiaty Nurung, Graduate Student PhD, Study Program : Science Of Public Administration. Hasanuddin University, Makassar, Indonesia. Email: jum.unhas@yahoo.com

Second Author - Rakhmat., Faculty Of Social Sciences and Political Sciences. Hasanuddin University, Makassar Third Author - Sulaeman Asang, Faculty Of Social Sciences and Political Sciences, Hasanuddin University, Makassa r Fourth Author - Hamsinah, Faculty Of Social Sciences and Political Sciences. Hasanuddin University, Makassar 